\title{
Doppler wind lidar using a MOPA semiconductor laser at stable single-frequency operation
}

Rodrigo, Peter John; Pedersen, Christian

Published in:

Conference abstract series, CLEO/Europe - EQEC

Link to article, DOI:

10.1109/CLEOE-EQEC.2009.5196300

Publication date:

2009

Document Version

Publisher's PDF, also known as Version of record

Link back to DTU Orbit

Citation (APA):

Rodrigo, P. J., \& Pedersen, C. (2009). Doppler wind lidar using a MOPA semiconductor laser at stable singlefrequency operation. In Conference abstract series, CLEO/Europe - EQEC (pp. 1-1). IEEE.

https://doi.org/10.1109/CLEOE-EQEC.2009.5196300

\section{General rights}

Copyright and moral rights for the publications made accessible in the public portal are retained by the authors and/or other copyright owners and it is a condition of accessing publications that users recognise and abide by the legal requirements associated with these rights.

- Users may download and print one copy of any publication from the public portal for the purpose of private study or research.

- You may not further distribute the material or use it for any profit-making activity or commercial gain

- You may freely distribute the URL identifying the publication in the public portal 


\title{
Doppler wind lidar using a MOPA semiconductor laser at stable single-frequency operation
}

\author{
Peter John Rodrigo and Christian Pedersen \\ DTU Fotonik, Technical University of Denmark, Frederiksborgvej 399, DK-4000 Roskilde, Denmark
}

Our group has recently demonstrated that a compact master-oscillator power-amplifier semiconductor laser (MOPA-SL) is a good candidate for a coherent light source (operating at $1550 \mathrm{~nm}$ ) in a Doppler wind Lidar [1]. The MOPA-SL requires two injection currents: $\mathrm{I}_{\mathrm{DFB}}$ for the distributed-feedback (DFB) laser section (master oscillator) and $\mathrm{I}_{\mathrm{AMP}}$ for the tapered amplifier section. For our laser, the specified maximum current values are $0.7 \mathrm{~A}$ and $4.0 \mathrm{~A}$ for $\mathrm{I}_{\mathrm{DFB}}$ and $\mathrm{I}_{\mathrm{AMP}}$, respectively. Figure 1(a) shows the measurement of $\mathrm{CW}$ output power of the MOPA-SL versus $\mathrm{I}_{\mathrm{AMP}}$ for three different values of $\mathrm{I}_{\mathrm{DFB}}=400,500$, and $600 \mathrm{~mA}$. Our measurements were taken at $19^{\circ} \mathrm{C}$ set temperature. The L-I curve shows that the output power linearly increases with $\mathrm{I}_{\mathrm{AMP}}$ and reaches an ample $1 \mathrm{~W}$ level. Although the MOPA-SL has been proven capable of producing single-frequency $\mathrm{CW}$ output beam, stable operation at this spectral condition has also been known to highly depend on the drive currents to the laser [2]. It is therefore important to identify pockets of stability in the $I_{\mathrm{DFB}}-\mathrm{I}_{\mathrm{AMP}}-\mathrm{T}_{\mathrm{S}}\left(\mathrm{T}_{\mathrm{S}}=\right.$ laser set temperature) space where lasting single-frequency operation is achieved. At a chosen set temperature $T_{S}=19^{\circ} \mathrm{C}$, we searched for combinations of $\left(\mathrm{I}_{\mathrm{DFB}}, \mathrm{I}_{\mathrm{AMP}}\right)$ where the laser operates stably at singlefrequency. This was done by observing the spectral characteristic of the laser using an optical spectrum analyzer (OSA, ANDO AQ6315) at different drive current combinations. The resolution of the OSA used is $0.05 \mathrm{~nm}$. Depending on the drive currents, single-frequency or multi-frequency operations of the laser may occur as shown in Fig 1(b). Furthermore, hysteretic mode-hops between single-frequency regimes can occur at higher values of $\mathrm{I}_{\mathrm{AMP}}$. When using the laser for a Doppler wind Lidar application, a combination of $\left(\mathrm{I}_{\mathrm{DFB}}, \mathrm{I}_{\mathrm{AMP}}\right)$ which is close to the center of an identified stable single-frequency regime is used. For the MOPA-SL unit that we use in our Lidar, we typically use $\left(\mathrm{I}_{\mathrm{DFB}}=0.5 \mathrm{~A}\right.$, $\mathrm{I}_{\mathrm{AMP}}=3.0 \mathrm{~A}$ ) at $\mathrm{T}_{\mathrm{S}}=19^{\circ} \mathrm{C}$. These current settings for the laser result in a highly stable Lidar as shown by a 5-day long continuous measurement of the Doppler shift produced by a constantly rotating diffusely reflecting target (Fig. 2).

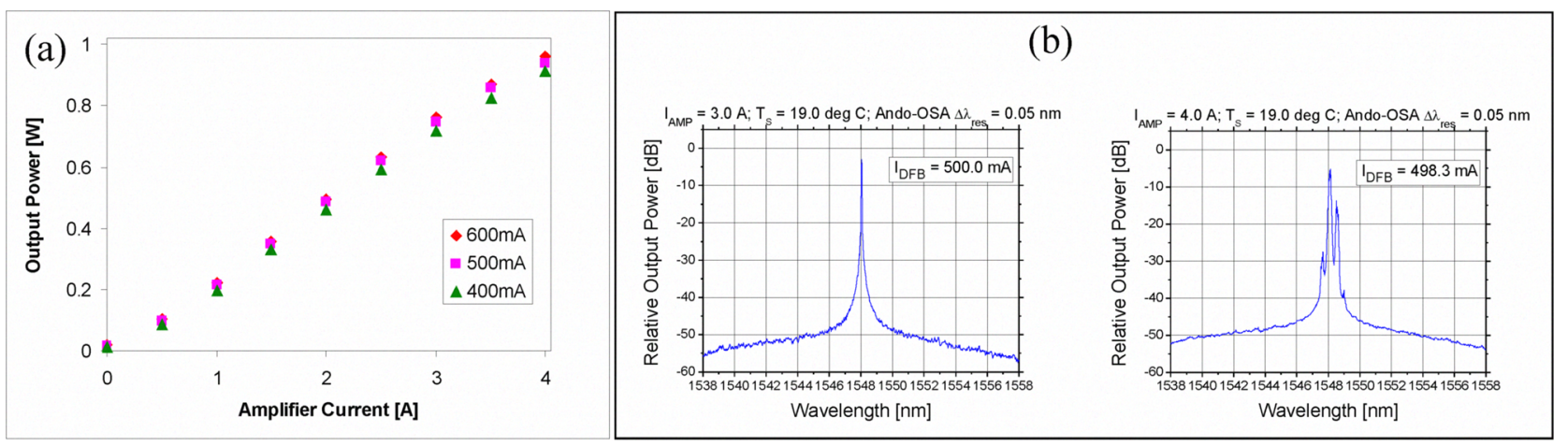

Fig. 1. Characterization of the MOPA-SL's (a) output power and (b) spectral properties for different drive currents.

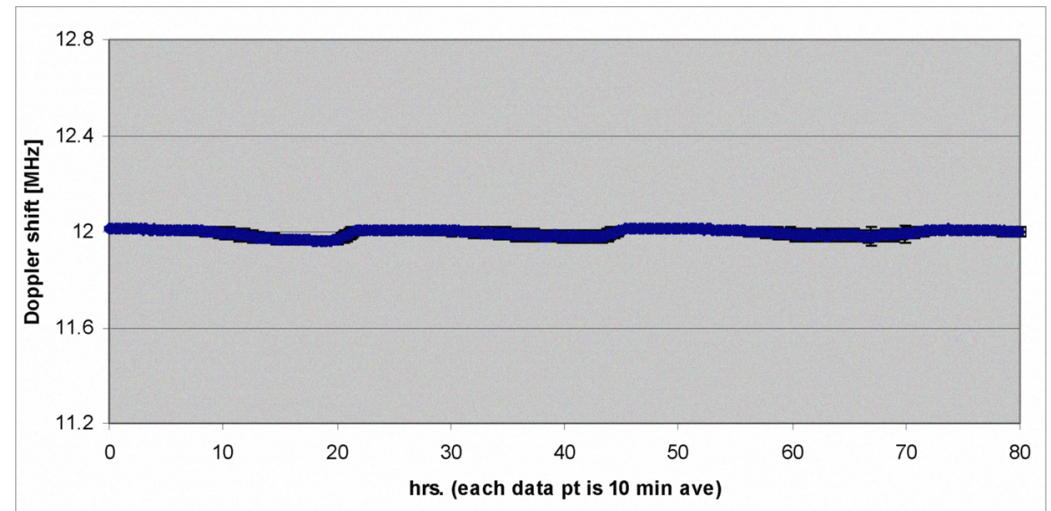

Fig. 2. Lidar-measured 10-minute average Doppler shift $(\sim 12 \mathrm{MHz})$ produced by a hard-target rotating at constant rate. Standard deviations of $<0.1 \mathrm{MHz}$ for any data point is indicative of the high stability of the laser source over an 80-hour period.

\section{References}

[1] R. S. Hansen and C. Pedersen, "All semiconductor laser Doppler anemometer at $1.55 \mu \mathrm{m}$," Opt. Express 16, 18288 (2008).

[2] A Egan, et al., "Dynamic Instabilities in Master Oscillator Power Amplifier Semiconductor Lasers," IEEE J. Quantum Electron. 34, 166 (1998). 